\title{
Silica burial enhanced by iron limitation in oceanic upwelling margins
}

\author{
L. E. Pichevin ${ }^{1 \star}$, R. S. Ganeshram ${ }^{1}$, W. Geibert ${ }^{1}$, R. Thunell ${ }^{2}$ and R. Hinton ${ }^{1}$
}

\begin{abstract}
In large swaths of the ocean, primary production by diatoms may be limited by the availability of silica, which in turn limits the biological uptake of carbon dioxide. The burial of biogenic silica in the form of opal is the main sink of marine silicon. Opal burial occurs in equal parts in iron-limited open-ocean provinces and upwelling margins, especially the eastern Pacific upwelling zone. However, it is unclear why opal burial is so efficient in this margin. Here we measure fluxes of biogenic material, concentrations of diatom-bound iron and silicon isotope ratios using sediment traps and a sediment core from the Gulf of California upwelling margin. In the sediment trap material, we find that periods of intense upwelling are associated with transient iron limitation that results in a high export of silica relative to organic carbon. A similar correlation between enhanced silica burial and iron limitation is evident in the sediment core, which spans the past 26,000 years. A global compilation also indicates that hotspots of silicon burial in the ocean are all characterized by high silica to organic carbon export ratios, a diagnostic trait for diatoms growing under iron stress. We therefore propose that prevailing conditions of silica limitation in the ocean are largely caused by iron deficiency imposing an indirect constraint on oceanic carbon uptake.
\end{abstract}

$\mathrm{D}$ iatoms, a group of phytoplankton with amorphous silica cell walls (opal), account for up to $40 \%$ of the marine primary production ${ }^{1}$. As their frustules are siliceous and contain no calcium carbonate, they export carbon to the deep ocean as organic matter. Hence, their relative abundance determines the organic to calcium carbonate ratio of settling biogenic particles from the sea surface: the $\mathrm{C}$ rain-rate ratio $^{2}$. This parameter regulates the efficiency of the biological pump of carbon by pushing the marine carbon cycle towards increased (high $\mathrm{C}$ rain-rate ratio) or decreased (low $\mathrm{C}$ rain-rate ratio) $\mathrm{CO}_{2}$ drawdown from the atmosphere ${ }^{3}$. In ideal conditions, diatoms need biologically available silicic acid and nitrate with a ratio of 1:1 in the surface waters ${ }^{4}$. However, whereas silicic acid is generally above biological requirements in the deep ocean relative to other macronutrients such as nitrate and phosphate, thermocline waters fuelling biological productivity in most parts of the ocean are depleted in silicic acid ${ }^{5}$. This leads to a yield limitation of diatom production by silicic acid in the surface ocean $^{6-8}$, restricting the amount of biogenic silica produced and hence the efficiency of the biological pump of carbon. Here we investigate the causes of this potentially widespread Si limitation in the ocean.

Silicon is introduced to the ocean through river runoff and is removed by sedimentary burial of mainly diatom opaline skeletal remains ${ }^{2,9}$. The ocean waters are undersaturated with respect to opal, and hence its burial efficiency is only 3\% because of dissolution in the water column and superficial sediments. On average, $\mathrm{Si}$ is recycled $\sim 25$ times within the ocean before permanent removal through sediment burial' . However, areas of high opal export also exhibit higher sedimentary $\mathrm{Si}$ burial rates as pore waters become rapidly supersaturated in silicic acid, preventing further dissolution and increasing $\mathrm{Si}$ burial ${ }^{10}$. Shallow water column and high sedimentation rates in margins further aid the burial of biogenic Si by reducing its exposure to undersaturated sea water ${ }^{2}$.

\section{Concurrence of marine Si sinks and Fe limitation}

Marine Si sinks are highly localized with burial mostly occurring in the Southern Ocean and the North Pacific for the open ocean (3 Tmol Si yr ${ }^{-1}$; ref. 11) and in continental margins

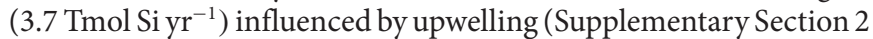
and Supplementary Table 1). Despite covering a small surface area, coastal upwelling areas represent the main Si sink in ocean margins. However, not all comparably productive marginal environments are Si sinks. This is often overlooked and remains unexplained ${ }^{12,13}$. For instance, Si burial rates in the eastern Pacific and Gulf of California $(\mathrm{GoC})$ upwelling regions are one to two orders of magnitude higher than in the Arabian Sea despite similar productivity levels ${ }^{12-14}$. Therefore, understanding why some oceanic margins are particularly efficient at removing $\mathrm{Si}$ is important in explaining silicic acid limitation in the surface ocean in view of the constraint it imposes on the biological C pump.

Areas of high opal production usually support significant organic carbon $\left(\mathrm{C}_{\text {org }}\right)$ export ${ }^{2}$ but there are notable exceptions to this ${ }^{15}$ (Fig. 1a,c). In the Southern Ocean, parts of the North Pacific and to a lesser extent the equatorial Pacific, $\mathrm{C}_{\text {org }}$ export is generally modest despite high biogenic silica fluxes. This results in very high biogenic silica to organic carbon $\left(\mathrm{Si} / \mathrm{C}_{\text {org }}\right)$ ratios in the settling particles (up to 10), in contrast to the rest of the ocean where the $\mathrm{Si} / \mathrm{C}_{\text {org }}$ ratio is generally below 1 (Fig. $1 \mathrm{c}$ and Supplementary Section 1 and Supplementary Fig. 1). The areas of high water column $\mathrm{Si}$ and $\mathrm{Si} / \mathrm{C}_{\text {org }}$ export in Fig. $\mathrm{lb}$ are also regions that support relatively large sedimentary Si burial (Supplementary Section 2 and Supplementary Fig. 3), suggesting a close link between water column and sediment fluxes. These large openocean regions with high Si exports are high nitrate-low chlorophyll (HNLC) areas characterized by micronutrient limitation. In the ocean interior, the dissolved iron concentration is generally below the biological requirement relative to essential macronutrients,

${ }^{1}$ School of Geosciences, Grant Institute, University of Edinburgh, West Main Road, Edinburgh EH9 3JW, UK, ${ }^{2}$ Department of Earth and Ocean Sciences, University of South Carolina, Columbia, South Carolina 29208, USA. *e-mail: laetitia.pichevin@ed.ac.uk 
leading to iron limitation in parts of the sea surface where additional continental supply of $\mathrm{Fe}$ is not sufficient ${ }^{16,17}$. The dearth of bio-available Fe from continental sources limits primary production and nitrate utilization in HNLC regions ${ }^{18,19}$. One direct consequence of this $\mathrm{Fe}$ deficiency is the depletion of silicic acid in these HNLC regions owing to the high uptake ratio of $\mathrm{Si}(\mathrm{OH})_{4}$ relative to carbon and other macronutrients by diatoms growing under $\mathrm{Fe}$ stress ${ }^{20,21}$. This overconsumption of silicic acid during diatom growth in turn leads to a high $\mathrm{Si} / \mathrm{C}_{\text {org }}$ ratio of the settling biogenic particles, thereby enhancing sedimentary $\mathrm{Si}$ burial. Similarly, in coastal areas the $\mathrm{Si} / \mathrm{C}_{\text {org }}$ ratio of settling particles varies greatly between margins. Continental margins that support high biogenic $\mathrm{Si}$ fluxes and burial such as the Eastern Pacific and the GoC show elevated $\mathrm{Si} / \mathrm{C}_{\text {org }}$ ratios (1-4.5), whereas biogenic fluxes in the Arabian Sea and the Benguela upwelling system exhibit $\mathrm{Si} / \mathrm{C}_{\text {org }}$ ratios $<1$ (Fig. 1c). Such very large variations cannot be simply explained by differences in silicic acid to nitrate and phosphate ratios of thermocline waters that upwell and fuel biological production. Further analyses of sediment trap data ${ }^{15}$ presented in Fig. 1c indicate that such a large contrast between margins cannot be explained solely by variations in siliceous versus calcareous primary producers or the differences in the ability of these skeletal remains to ballast organic carbon. Instead, the high $\mathrm{Si} / \mathrm{C}_{\text {org }}$ fluxes $(>1)$ are related to high elemental $\mathrm{Si} / \mathrm{C}$ ratios of the siliceous producers themselves (Supplementary Section 1 and Supplementary Fig. 2). Notionally, unlike open-ocean HNLC provinces, coastal upwelling areas receive additional iron inputs from the shelf and continental sources and are not expected to be iron-limited. However, recent evidence suggests that iron limitation can arise even in coastal systems during the course of intense upwelling when these additional terrestrial $\mathrm{Fe}$ inputs are not sufficient to meet consumption by biota ${ }^{22-25}$. Here, using a suit of diatom-bound geochemical tracers, we demonstrate that high $\mathrm{Si} / \mathrm{C}_{\text {org }}$ export ratios and biogenic silica burial in some upwelling margins can be attributed to iron limitation. We focus on the GoC, which constitutes a large Si sink despite its small size and is widely regarded as the archetypal area for the formation of diatomaceous sediments ${ }^{26}$.

\section{Opal exports in the Gulf of California}

Biogenic silica fluxes and the $\mathrm{Si} / \mathrm{C}_{\text {org }}$ ratio of the settling particles recorded between 1990 and 1997 in a sediment trap from the GoC are shown in Fig. $2 \mathrm{a}$ (ref. 14). The $\mathrm{Si} / \mathrm{C}_{\text {org }}$ ratio increases markedly during winter, when intense upwelling conditions prevail, leading to extremely high silica export to the sediment. Diatoms, the main siliceous producers, ideally need a silicic acid to nitrate ratio of about 1 (ref. 4). With a nutrient ratio of 1.8 in the subsurface water, silicic acid supplied to the biota is in excess relative to nitrate in the GoC (ref. 27). Yet $\mathrm{Si}(\mathrm{OH})_{4}$ becomes completely used by the phytoplankton at the sea surface over the course of the upwelling season during 'normal' years ${ }^{27}$ (Supplementary Methods 3). This apparent surfeit silicic acid consumption in the photic zone and the elevated $\mathrm{Si} / \mathrm{C}_{\text {org }}$ rain-rate ratio, comparable to $\mathrm{HNLC}$ regions such as the Southern Ocean, together point to increased $\mathrm{SiOH}_{4}$ uptake by diatoms, greater export of biogenic silica relative to $\mathrm{C}_{\text {org }}$ during the productive season, and are diagnostic characteristics of the effect of iron limitation on diatoms ${ }^{23}$.

This inference is supported by the near-complete depletion of dissolved $\mathrm{Fe}(\mathrm{dFe})$ in the surface waters of the central region of the $\mathrm{GoC}$ and the low $\mathrm{dFe} / \mathrm{PO}_{4}$ ratios (generally $<10^{-3}$ ) in subsurface waters ${ }^{28}$ falling well below the lower limit of the optimum subsistence ratio for coastal diatoms and close to the limit for other phytoplankton groups ${ }^{17,29}$ (Supplementary Methods 4). This suggests that the GoC may be iron-limited during upwelling seasons when diatom production and biological consumption of both macro- and micro-nutrients increases ${ }^{23,24}$.
In addition to the $\mathrm{Si} / \mathrm{C}_{\text {org }}$ rain-rate ratio, we track seasonal changes in the biological availability of dissolved Fe in the GoC using the trace metal composition of isolated and cleaned diatom frustules from the sediment trap samples collected between March 1996 and February 1997 (ref. 14; Fig. 2a). In Supplementary Section 3.3 and Supplementary Fig. 5, we show that Fe concentrations in diatom frustules track iron availability in natural sea water. In the $\mathrm{GoC}, \mathrm{Fe} / \mathrm{SiO}_{2}$ ratios are elevated during the summer months (July and August) when the water column is stratified owing to weak, southerly winds and productivity is at its lowest ${ }^{14,27}$. Iron measurements in the surface water of GoC corroborate this finding and reveal high $\mathrm{dFe}$ concentrations and a $\mathrm{dFe} /$ macronutrient ratio in excess relative to biological requirement under stratified conditions due to terrestrial $\mathrm{Fe}$ inputs ${ }^{28}$. After stratification breaks down, $\mathrm{Fe}$ concentrations in the diatom frustules decrease by a factor of 5 on average (Fig. 2b). The lowest $\mathrm{Fe} / \mathrm{SiO}_{2}$ ratios are generally associated with the highest $\mathrm{Si} / \mathrm{C}_{\text {org }}$ ratio in settling particles and elevated biogenic silica fluxes, typically $>1,500 \mathrm{mmol} \mathrm{m}^{-2} \mathrm{yr}^{-1}$. The initial decrease in Fe availability (October) occurs in conjunction with increased biogenic carbon fluxes (carbonate and $\mathrm{C}_{\text {org }}$ ) at the beginning of the upwelling season but before the biogenic silica peak, further documenting the sequence of events in the basin: increased biological consumption of iron in the surface and upwelling of Fe-deficient water from the subsurface trigger Fe limitation, which in turn causes a marked increase in Si export as a result of the increased $\mathrm{Si} / \mathrm{C}$ uptake ratio by diatoms. Fe availability remains low during late winter-early spring and is replenished only in the summer when the water column becomes stratified and biological production reaches a minimum. Therefore, we suggest that conditions of transient iron limitation in the GoC fostered by high biological productivity following intense upwelling events result in high biogenic $\mathrm{Si}$ and $\mathrm{Si} / \mathrm{C}_{\text {org }}$ fluxes ${ }^{17,20}$ causing the $\mathrm{GoC}$ to operate as an enhanced $\mathrm{Si} \operatorname{sink}^{27}$.

It is important to recognize that in this scenario, Fe limitation is caused by intense upwelling of waters that are deficient in $\mathrm{Fe}$ relative to other macronutrients such that the supply of Fe from continental sources is insufficient to raise Fe levels to meet biological uptake. Thus, dampened upwelling should reduce the amount of micronutrient required from terrestrial sources to consume upwelled macronutrients. This in turn could lift Fe limitation. Such conditions occur during El Niño episodes, such as the 1991 event, in the Gulf of California (Fig. 2a). As seen in Fig. 2a,c, biogenic Si fluxes and the seasonal sharp increase in the $\mathrm{Si} / \mathrm{C}_{\text {org }}$ ratio of settling particles are much less pronounced during El Niño than during intense upwelling years. In addition, excess silicic acid has been reported in the GoC during El Niño events, once again reflecting reduced $\mathrm{Si}$ uptake relative to other macronutrients ${ }^{27}$. As a corollary, we suggest that climatic periods characterized by dampened winter upwelling conditions will see the relaxation of Fe limitation in the basin, a significant reduction in $\mathrm{Si}$ burial and the build up of unutilized silicic acid at the sea surface.

\section{Pleistocene opal burial in the Gulf of California}

We examine this scenario using high-resolution sedimentary records from the GoC (Fig. 3). Pronounced declines in Si burial rates have been reported during Heinrich events-cold climatic periods in the Northern Hemisphere when eastern Pacific margins including the GoC experience reduced upwelling ${ }^{30}$. In particular, we explore whether such reduction in biogenic Si burial is matched by increased Fe biological availability and excess photic zone silicic acid by combining estimates of diatom-bound $\mathrm{Fe}$ and $\mathrm{Si}$ isotope ratios in Core MD02-2515. These long-term records suggest that the GoC has been operating in two modes with respect to iron status (replete versus limited) during the past $26 \mathrm{kyr}$. Periods of high Si burial and $\mathrm{Si} / \mathrm{C}_{\text {org }}$ ratios at the core site correspond to periods of low diatom $\mathrm{Fe} / \mathrm{SiO}_{2}$ ratios and elevated $\delta^{30} \mathrm{Si}(\sim 1.2 \%)$. On the other hand, the 

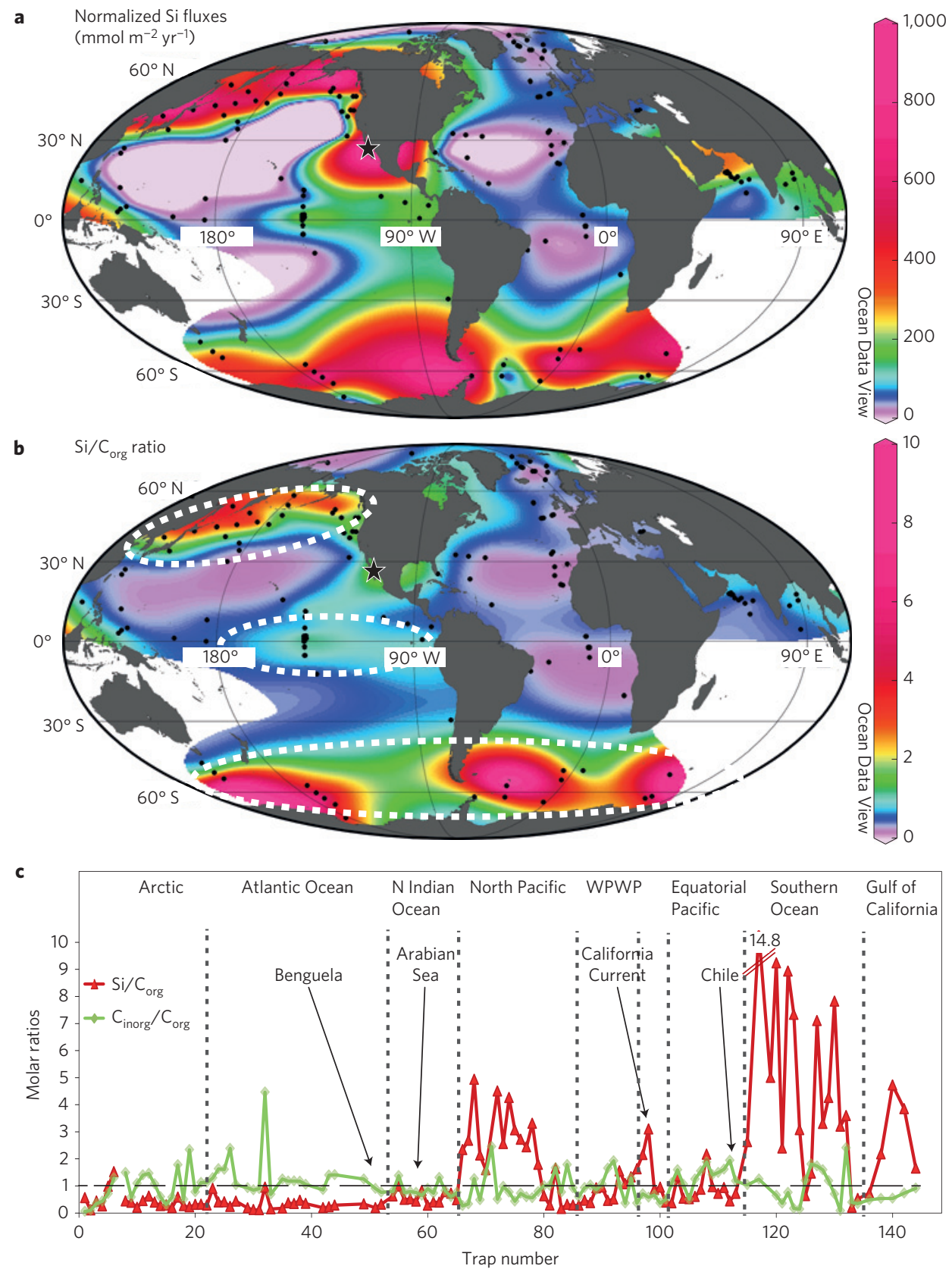

Figure 1 | The distribution of biogenic silica fluxes and molar biogenic silica $(\mathrm{Si})$ to organic carbon $\left(\mathrm{Si} / \mathrm{C}_{\text {org }}\right.$ ) ratios shows the variability in $\mathrm{Si} / \mathrm{C}_{\text {org }}$ ratio among a wide range of oceanic provinces. a,b, Ocean Data View maps and shading are derived from the US Joint Global Ocean Flux study ${ }^{15}$ (JGOFS, black dots) and the Guaymas Basin, Gulf of California ${ }^{14}$ (black star) sediment trap data. HNLC regions (dotted white ellipses) and the North East Pacific margin exhibit higher $\mathrm{Si} / \mathrm{C}_{\text {org }}$ export ratio than the surrounding open ocean. $\mathbf{c}$, $\mathrm{C}_{\text {org }}$ normalized biogenic $\mathrm{Si}$ and inorganic carbon ( $\mathrm{C}_{\text {inorg}}$ ) ratios in JGOFS sediment traps.

onsets of Heinrich events at 17 and $12.5 \mathrm{kyr} \mathrm{BP}$ are characterized by a decrease in $\mathrm{Si}$ burial and $\mathrm{Si} / \mathrm{C}_{\text {org }}$ ratios, low $\delta^{30} \mathrm{Si}$ and high $\mathrm{Fe} / \mathrm{SiO}_{2}$. The $\delta^{30} \mathrm{Si}$ of dissolved silicic acid supplied to the GoC is estimated to be around $1.2 \%$ (refs 31,32). Using a Raleigh fractionation model in a closed system (Supplementary Section 4.2), we calculate that episodes of high opal burial correspond with periods of complete silicic acid utilization in the GoC by biota ${ }^{27}$. Given that the silicic acid to nitrate ratio is about 1.8 in the GoC (ref. 27), complete silicic acid utilization in upwelled waters requires diatom uptake of these nutrients in proportions $>1$, which is typical of iron-limited conditions ${ }^{20,22,33}$. This is evident from the low $\mathrm{Fe} / \mathrm{SiO}_{2}$ recorded by diatoms during these periods. In contrast, Heinrich events were matched by two- to threefold higher diatom-bound $\mathrm{Fe} / \mathrm{SiO}_{2}$ than the rest of the record, suggesting that Fe biological availability increased during diatom growth in these intervals. Assuming that the silicate to nitrate ratio of upwelling waters remained at 1.8 , to achieve $\sim 50 \%$ silicic acid relative utilization diatoms should have consumed silicic acid and nitrate at a ratio close to 1 . This uptake ratio of 1 suggests diatom growth under Fe-replete conditions and diatom opal yield limited only by $\mathrm{N}$. Therefore, the $\delta^{30} \mathrm{Si}$ values measured during Heinrich events are consistent with the absence of Fe limitation. Importantly, these results suggest that the declines in Si burial during Heinrich events resulted from reduced Si uptake relative to other macronutrients by diatoms growing under $\mathrm{Fe}$ replete conditions, leaving surplus silicic acid at the surface of GoC. These conditions are similar to observations during modern El Niño 
a

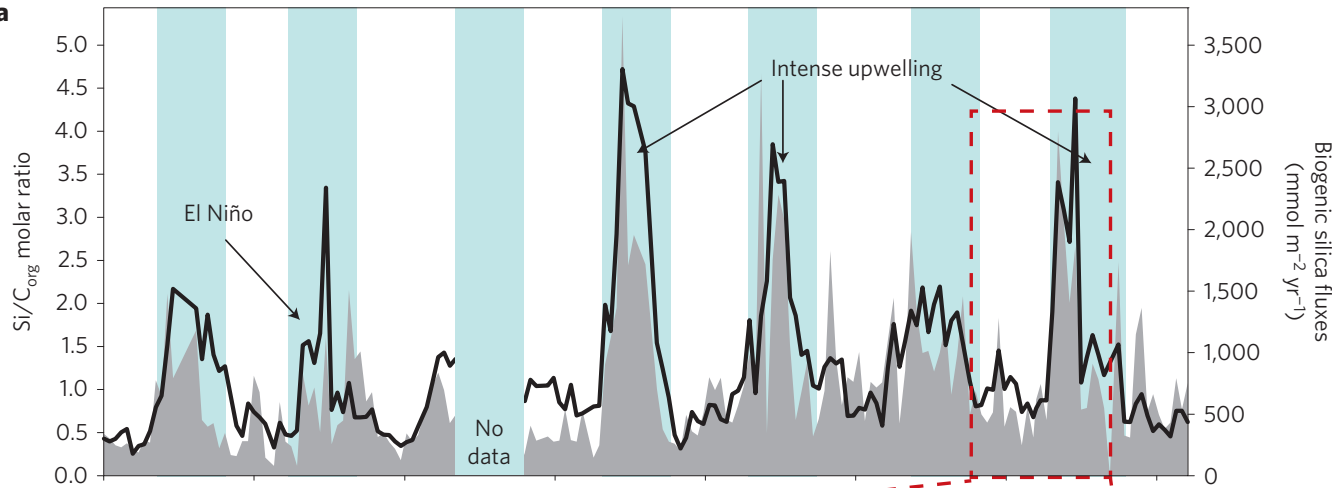

08/07/1990 08/07/1991 08/07/1992 08/07/1993 08/07/7994-08/07/19̄- 005 $08 / 07 / 1996 \quad 08 / 07 / 1997$

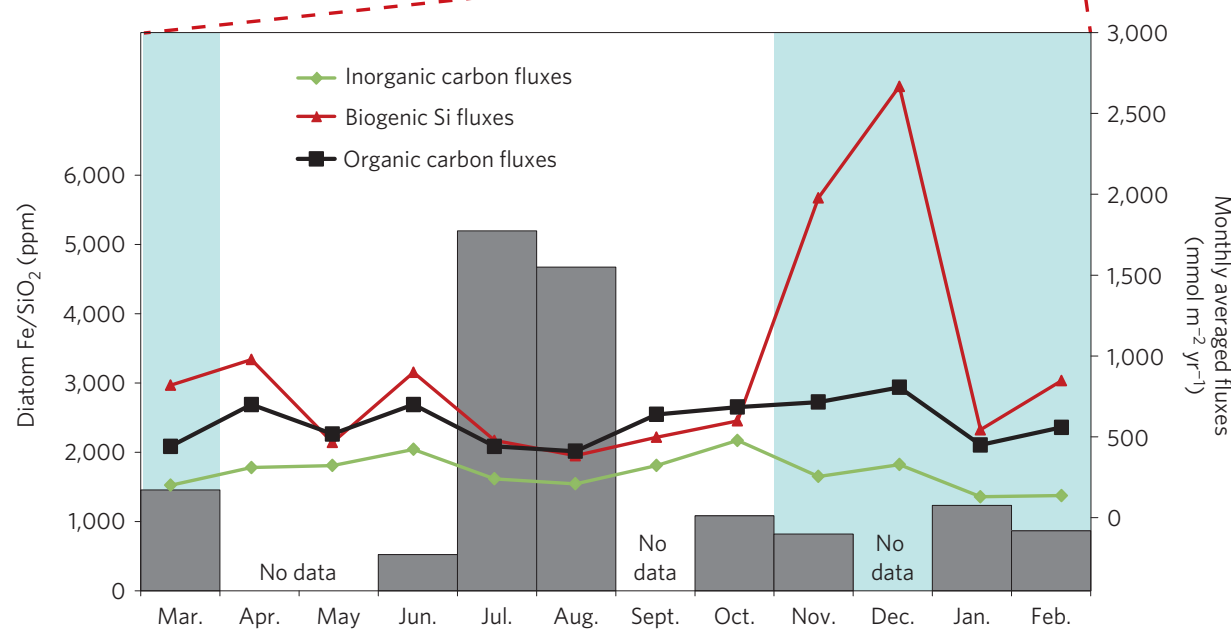

c
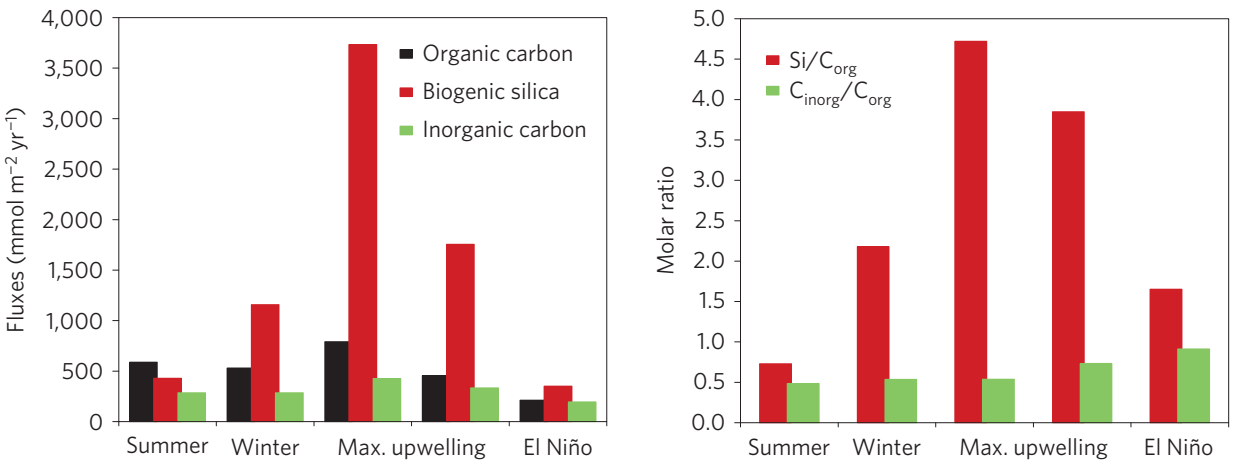

Figure 2 | Biogenic fluxes, Si/C $\mathrm{C}_{\text {org }}$ ratio and diatom-bound Fe in the Gulf of California sediment trap. a, Si fluxes and Si/Corg ratios markedly increase during winter upwelling (blue stripes). b, A close-up of the year 1996-1997 shows that Fe/SiO 2 (ppm, grey bars) is high during the stratified period and decreases during the upwelling season when inorganic and organic carbon fluxes increase. c, 1990-1997 average biogenic flux changes in the Gulf of

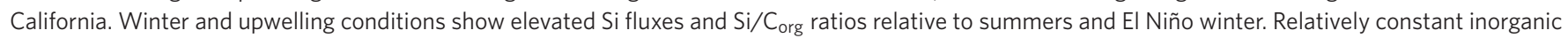
carbon $\left(\mathrm{C}_{\text {inorg }}\right.$ ) suggests that $\mathrm{Si} / \mathrm{C}_{\text {org }}$ variations are not related to calcareous production.

episodes in the GoC (ref. 27). This case study illustrates the switch from $\mathrm{N}$ limitation during dampened upwelling (El Niño) to $\mathrm{Si}$ limitation during intense upwelling periods (for example, La Niña) due to increased diatom $\mathrm{Si}(\mathrm{OH})_{4} / \mathrm{NO}_{3^{-}}$uptake ratios under $\mathrm{Fe}$ stress. In addition, our sedimentary records suggest that intense upwelling conditions increase the biological consumption of Fe and the resultant transient Fe limitation is the key factor that enhances biogenic silica burial rates in the GoC.

\section{Implications for the marine silicon budget}

The episodic nature of the upwelling process and the strong biological requirement for $\mathrm{dFe}$ imposed on restricted time and spatial scales make upwelling margins prone to transient $\mathrm{Fe}$ limitation, although at variable frequency and intensity subject to local conditions causing large differences in Si burial between upwelling margins. Upwelling margins such as the eastern Pacific with high opal burial also show high $\mathrm{Si} / \mathrm{C}_{\text {org }}$ export in the water column (Fig. 1a and Supplementary Section 2 and Supplementary Fig. 3). This suggests that Fe limitation is a key factor enhancing opal burial in these margins as our case study in the GoC illustrates. Eastern Pacific margins, where previous studies have reported transient Fe limitation, are an important contributor to the marine Si sink and could possibly account for the burial of $1.5 \mathrm{Tmol} \mathrm{Si} \mathrm{yr}^{-1}$ or $\sim 25 \%$ of the marine Si sink. This is comparable to the largest open-ocean Si sinks in the North Pacific and the Southern Ocean (Supplementary Table 1 and Supplementary Section 2). We estimate 


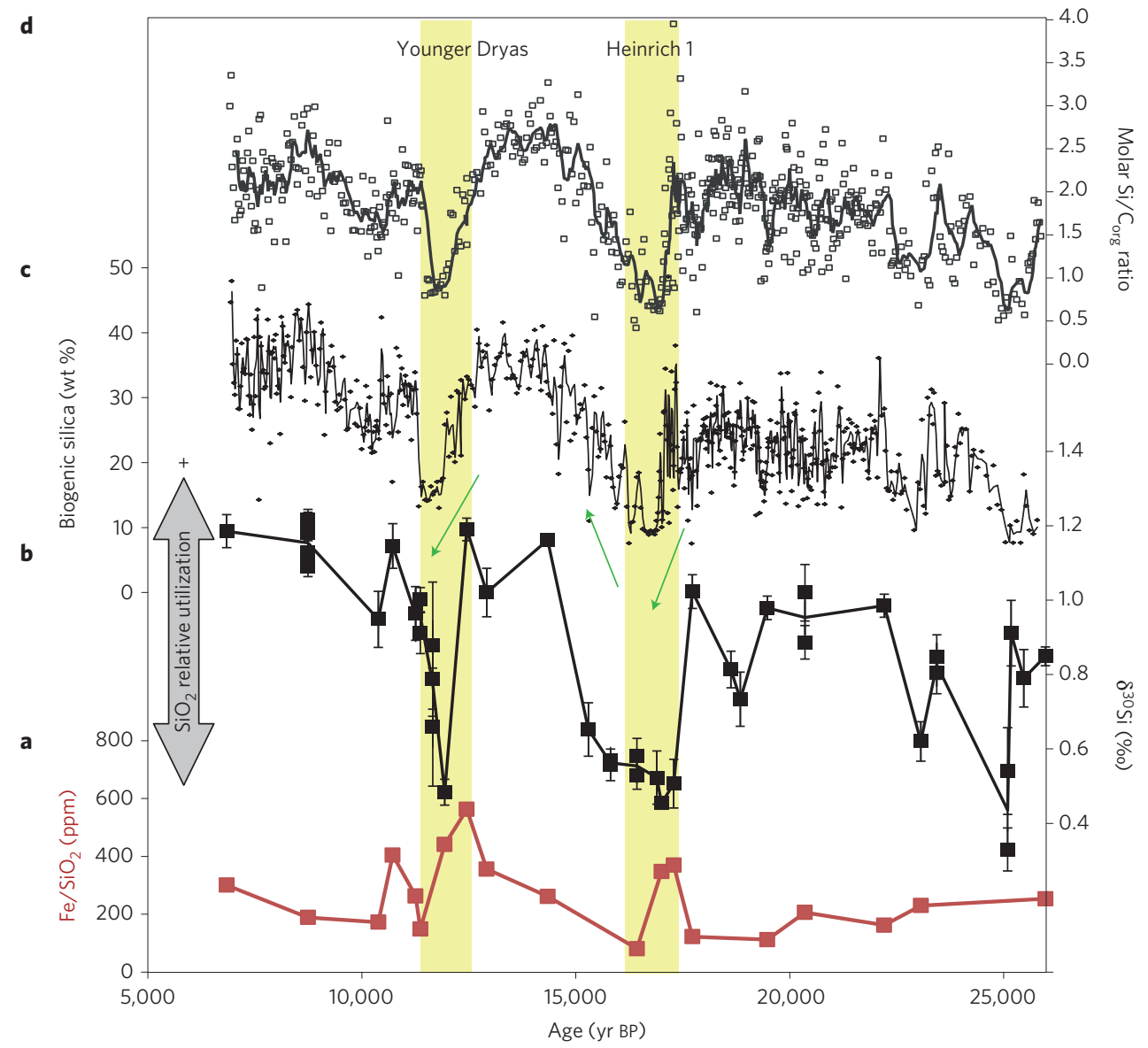

Figure 3 | Multiproxy reconstruction of silica cycling and iron biological availability in the Gulf of California over the last climatic cycle in core MD $02-2515\left(27^{\circ} 53^{\prime} \mathrm{N}, 111^{\circ} 40^{\prime} \mathrm{W}\right.$ ) illustrates the long-term impact of Fe limitation on Si burial. a-d, Diatom-bound Fe (a) increases at the onset of Heinrich event 1 and the Younger Dryas period (light green columns), in conjunction with decreasing silicic acid relative utilization ( $\delta^{30}$ Si; b; ref. 27), biogenic silica concentration (c) and molar $\mathrm{Si} / \mathrm{C}_{\text {org }}$ ratio (d).

from our global compilation that between 60 and $75 \%$ of the total Si sink may occur in open ocean and margins where Fe limitation is prevalent. Without these Si burial hotspots, oceanic Si limitation ${ }^{5,6}$ would be much diminished. Thus, our study reveals the intrinsic link between $\mathrm{Fe}$ stress and $\mathrm{Si}$ removal from the ocean and the indirect constraint imposed by $\mathrm{Fe}$ on the $\mathrm{C}$ rain-rate ratio and oceanic $\mathrm{CO}_{2}$ uptake by fostering Si deficiency in the ocean.

\section{Methods}

Silicon isotope determination was conducted at ETH Zürich. A small amount of biogenic opal $(0.5 \mathrm{mg})$ was dried down with concentrated perchloric acid at $\sim 180^{\circ} \mathrm{C}$ in Teflon vials, and then dissolved in $100 \mu \mathrm{l}$ of $1 \mathrm{M} \mathrm{NaOH}$, before being diluted to $5 \mathrm{ml}$ with $0.01 \mathrm{M} \mathrm{HCl}$ after $24 \mathrm{~h}$. Equivalent to $10 \mu \mathrm{g}$ of opal was loaded onto a pre-cleaned $1.8 \mathrm{ml}$ DOWEX 50W-X12 cation exchange resin bed (in $\mathrm{H}^{+}$ form) and eluted with $5 \mathrm{ml}$ of purified water (Milli-Q element $18.2 \mathrm{M} \Omega \mathrm{cm}^{-1}$ ). The $\mathrm{Si}$ isotope composition was determined on the diluted solution $(0.6 \mathrm{ppm} \mathrm{Si})$ on the Nu1700 high-resolution MC-ICPMS at ETH Zürich, using a standard-sample-standard bracketing protoco ${ }^{34,35}$. All results in this study were calculated using the $\delta^{30} \mathrm{Si}$ notation for deviations of the measured ${ }^{30} \mathrm{Si} /{ }^{28} \mathrm{Si}$ from the international Si standard NBS28 in parts per thousand (\%). The long-term reproducibility was better than $0.07 \% 0 \delta^{30} \mathrm{Si}$ (1 s.d.). Samples were measured at least 5 times, which resulted in a $95 \%$ confidence level below $0.08 \%$.

The trace metal measurements on cleaned diatom frustules ${ }^{36,37}$ were performed using an Ion Microprobe Cameca ims-4f at the NERC (National Environment Research Council) Microprobe Facility located at the School of Geosciences, University of Edinburgh. The clean diatom samples $(2 \mathrm{mg})$ were pressed into an indium foil and analysed several (10-12) times for up to 10 cycles with the ion microprobe. We used a $10 \mathrm{nA}$ primary beam, $25 \mu \mathrm{m}$ image field and energy filtering $(75 \mathrm{eV})$. The metal/ $\mathrm{SiO}_{2}$ values represent the average of the $10-12$ measurements made for each sample.
Received 21 December 2013; accepted 6 May 2014; published online 8 June 2014

\section{References}

1. Nelson, D. M., Treguer, P., Brzezinski, M. A., Leynaert, A. \& Queguiner, B. Production and dissolution of biogenic silica in the ocean-revised global estimates, comparison with regional data and relationship to biogenic sedimentation. Glob. Biogeochem. Cycles 9, 359-372 (1995).

2. Ragueneau, O. et al. A review of the Si cycle in the modem ocean: Recent progress and missing gaps in the application of biogenic opal as a paleoproductivity proxy. Glob. Planet. Change 26, 317-365 (2000).

3. Archer, D. \& Maier-reimer, E. Effect of deep-sea sedimentary calcite preservation on atmospheric $\mathrm{CO}_{2}$ concentration. Nature 367, 260-263 (1994).

4. Brzezinski, M. A. The Si-C-N ratio of marine diatoms-interspecific variability and the effect of some environmental variables. J. Phycol. 21, 347-357 (1985)

5. Sarmiento, J. L., Gruber, N., Brzezinski, M. A. \& Dunne, J. P. High-latitude controls of thermocline nutrients and low latitude biological productivity. Nature 427, 56-60 (2004).

6. Moore, J. K., Doney, S. C. \& Lindsay, K. Upper ocean ecosystem dynamics and iron cycling in a global three-dimensional model. Glob. Biogeochem. Cycles 18, GB4028 (2004).

7. Dugdale, R. C., Wilkerson, F. P. \& Minas, H. J. The role of a silicate pump in driving new production. Deep-Sea Res. I 42, 697-719 (1995).

8. Dugdale, R. C. \& Wilkerson, F. P. Silicate regulation of new production in the equatorial Pacific upwelling. Nature 391, 270-273 (1998).

9. Tréguer, P. et al. The silica balance in the world ocean: A reestimate. Science 268, 375-379 (1995).

10. Broecker, W. S. \& Peng, T. H. Tracers in the Sea (Eldigio Press, 1984).

11. Tréguer, P. \& De La Rocha, C. The world ocean silica cycle. Ann. Rev. Mar. Sci. 5, 477-501 (2013). 
12. Sirocko, F. Deep-sea sediments of the arabian sea-a paleoclimatic record of the southwest-asian summer monsoon. Geol. Rundsch. 80, 557-566 (1991).

13. Demaster, D. J. The supply and accumulation of silica in the marine-environment. Geochim. Cosmochim. Acta 45, 1715-1732 (1981).

14. Thunell, R. C. Seasonal and annual variability in particle fluxes in the Gulf of California: A response to climate forcing. Deep-Sea Res. I 45, 2059-2083 (1998).

15. Honjo, S., Steven, J. M., Richard, A. K. \& Roger, F. Particulate organic carbon fluxes to the ocean interior and factors controlling the biological pump: A synthesis of global sediment trap programs since 1983. Prog. Oceanogr. 76, 217-285 (2008).

16. Jickells, T. D. et al. Global iron connections between desert dust, ocean biogeochemistry, and climate. Science 308, 67-71 (2005).

17. Brand, L. E. Minimum iron requirements of marine-phytoplankton and the implications for the biogeochemical control of new production. Limnol. Oceanogr. 36, 1756-1771 (1991).

18. Martin, J. H. et al. Testing the iron hypothesis in ecosystems of the equatorial Pacific Ocean. Nature 371, 123-129 (1994).

19. Falkowski, P. G. Evolution of the nitrogen cycle and its influence on the biological sequestration of $\mathrm{CO}_{2}$ in the ocean. Nature 387, 272-275 (1997).

20. Takeda, S. Influence of iron availability on nutrient consumption ratio of diatoms in oceanic waters. Nature 393, 774-777 (1998).

21. Brzezinski, M. A. et al. A switch from $\mathrm{Si}(\mathrm{OH})(4)$ to NO3-depletion in the glacial Southern Ocean. Geophys. Res. Lett. 29, 1564 (2002).

22. Hutchins, D. A. \& Bruland, K. W. Iron-limited diatom growth and Si:N uptake ratios in a coastal upwelling regime. Nature 393, 561-564 (1998)

23. Firme, G. F., Rue, E. L., Weeks, D. A., Bruland, K. W. \& Hutchins, D. A. Spatial and temporal variability in phytoplankton iron limitation along the California coast and consequences for Si, N, and C biogeochemistry. Glob. Biogeochem. Cycles 17, 1016 (2003).

24. Fitzwater, S. E. et al. Iron, nutrient and phytoplankton biomass relationships in upwelled waters of the California coastal system. Cont. Shelf Res. 23, 1523-1544 (2003).

25. Chase, Z. et al. Manganese and iron distributions off central California influenced by upwelling and shelf width. Mar. Chem. 95, 235-254 (2005)

26. Calvert, S. E. Accumulation of diatomaceous silica in the sediments of Gulf of California. Geol. Soc. Am. Bull. 77, 569-596 (1966).

27. Pichevin, L. et al. Silicic acid biogeochemistry in the Gulf of California: Insights from sedimentary Si isotopes. Paleoceanography 27, PA2201 (2012).

28. Segovia-Zavala, J. A., Lares, M. L., Delgadillo-Hinojosa, F., Tovar-Sanchez, A. \& Sanudo-Wilhelmy, S. A. Dissolved iron distributions in the central region of the Gulf of California, Mexico. Deep-Sea Res. I 57, 53-64 (2010).

29. Twining, B. S. et al. Metal quotas of plankton in the equatorial Pacific Ocean. Deep-Sea Res. II 58, 325-341 (2011).

30. Arellano-Torres, E., Pichevin, L. E. \& Ganeshram, R. S. High-resolution opal records from the eastern tropical Pacific provide evidence for silicic acid leakage from HNLC regions during glacial periods. Quat. Sci. Rev. 30, 1112-1121 (2011).

31. De la Rocha, C. L., Brzezinski, M. A. \& DeNiro, M. J. A first look at the distribution of the stable isotopes of silicon in natural waters. Geochim. Cosmochim. Acta 64, 2467-2477 (2000).

32. Reynolds, B. C., Frank, M. \& Halliday, A. N. Silicon isotope fractionation during nutrient utilization in the North Pacific. Earth Planet. Sci. Lett. 244, 431-443 (2006)

33. Franck, V. M., Brzezinski, M. A., Coale, K. H. \& Nelson, D. M. Iron and silicic acid concentrations regulate Si uptake north and south of the Polar Frontal Zone in the Pacific Sector of the Southern Ocean. Deep-Sea Res. II 47, 3315-3338 (2000).

34. Georg, R. B., Reynolds, B. C., Frank, M. \& Halliday, A. N. New sample preparation techniques for the determination of $\mathrm{Si}$ isotopic compositions using MC-ICPMS. Chem. Geol. 235, 95-104 (2006).

35. Reynolds, B. C., Georg, R. B., Oberli, F., Wiechert, U. H. \& Halliday, A. N. $\mathrm{Re}$-assessment of silicon isotope reference materials using high-resolution multi-collector ICP-MS. J. Anal. At. Spectrom. 21, 266-269 (2006).

36. Morley, D. W. et al. Cleaning of lake sediment samples for diatom oxygen isotope analysis. J. Paleolimnol. 31, 391-401 (2004).

37. Ellwood, M. J. \& Hunter, K. A. Determination of the $\mathrm{Zn} / \mathrm{Si}$ ratio in diatom opal: A method for the separation, cleaning and dissolution of diatoms. Mar. Chem. 66, 149-160 (1999).

\section{Acknowledgements}

We thank S. Calvert, K. Darling and B. Reynolds for discussions. Financial support for this project was provided by the Scottish Alliance for Geoscience Environment Society (SAGES), and the Natural Environment Research Council (NERC) through a Standard NERC grant to R.S.G. and L.E.P. Sediment Core MD 02-2515 was retrieved during the MONA (Marges Ouest Nord Américaines) cruise of the RV Marion Dufresne (International Marine Global Changes-IMAGES VIII) in June 2002

\section{Author contributions}

L.E.P. and R.S.G. initiated the project. L.E.P. and R.H. measured diatom-bound trace metals, L.E.P. measured elemental composition and silicon isotopes, W.G. and R.T. provided samples for diatom-bound trace metal measurements, and L.E.P. and R.S.G. wrote the paper with the participation of W.G. All authors were involved in the discussions of the results and commented on the manuscript.

\section{Additional information}

Supplementary information is available in the online version of the paper. Reprints and permissions information is available online at www.nature.com/reprints. Correspondence and requests for materials should be addressed to L.E.P.

\section{Competing financial interests}

The authors declare no competing financial interests. 